\title{
School Leadership in Higher Institutions of Learning: Opportunities for Sustainable Development
}

\author{
Article by Kaahwa Maria-Goretti ${ }^{1}$, Buregea Bin Rwakenda Henri ${ }^{2}$ \\ ${ }^{1}$ PhD, Faculty of Education; Senior Lecturer and Quality Assurance Director, Kyambogo \\ University \\ ${ }^{2} \mathrm{PhD}$, Texila American University, \\ Email:Kaahwa.goretti@yahoo.com ${ }^{1}$,henry.buregea@texilaconnect.com ${ }^{2}$
}

\begin{abstract}
Governments of Uganda and schools in Uganda have made great efforts to develop the education sector for quality education through Higher Institutions of Learning. In Uganda, the number of these institutions has increased since almost four decades. Unfortunately, through different tracer studies, statistics show that employments are rare to the African graduates and worse in Uganda. Youth unemployment in Uganda is the highest in Africa. More than $62 \%$ of graduates in Uganda are not employed and the African development Bank says it could be as high as $83 \%$. The main question was to find out all opportunities in Higher Institutions of Learning that could enable graduates and Mbale District dwellers to induce, maintain, and promote sustainable development. The purpose of the research was therefore to identify those opportunities in Higher Institutions of Learning that can be useful to sustainable development of Mbale. The research was conducted in Uganda in Mbale District. The method of research was qualitative. The researcher used interview as well as moderator guides as tools for data collection. The sampling technique was random and convenient in nature. The findings were critically examined and faithfully reported. Identified opportunities in Higher Institutions of Learning were essentially: guided skills based knowledge, technologies, scientific know-how that can be used to induce, maintain, and promote sustainable development through global education, research, and technology and all findings have to lead to special approaches that will satisfy the needs of people in Mbale, Uganda and the world.
\end{abstract}

Keywords: School leadership, Higher Institutions of Learning, Integral Development.

\section{Introduction}

A history of Higher Education reveals that universities and colleges have been at the forefront of creating as well as deconstructing paradigms. They have led social change through scientific breakthroughs but also through education of intellectuals, leaders and future makers (Cortese et al. cited by Tilbury, 2014). African leaders at independence strongly believed that the economic stagnation of their countries resulted from a shortage of qualified technical and managerial cadres (Musaazi, 2011). Musaazi further posits that development is an educational process. The concept of development as a process overtime has important implications for the overall development planning of a country. Trust in the ability of education to promote economic and social development is a common thing in Africa Today. Development must emphasize employment, income distribution, self-reliance and commitment (op. Cit.). This crucial to know if the emphasis is on sustainability and the role higher education can play.

Unfortunately, Statistics show that employments are very rare to the African graduate and worse in Uganda. In fact statistics show that there is job scarcity in Uganda. The Vice Chancellor's Forum (2016) indicate that more than 400.000 Students (who) graduate from Higher Institutions of Learning (HIL) but only 150.000 get jobs. It is therefore important that HIL organize an education system that will promote job creation for wealth creation. 
DOI: 10.21522/TIJAR.2014.04.02.Art004

ISSN: $2520-3088$

\section{School leadership}

School leadership is the most important factor of success in education. This is a reality that affects school administration from home, kindergarten, elementary, secondary, to university level in both public and private education systems. School leadership is second only to teaching among school-related factors in its impact on student learning according to research (Wallace Foundation, 2016).

The school leader of today must play a panoply of roles, engage in a plethora of activities, and make a myriad of decisions to ensure student learning. During schooling, leaders have to identify opportunities in HIL and in the district that can lead to sustainable development. Identification of opportunities should be one of the priorities of school leadership at all levels but for the sake of this study, the focus is on opportunities in HIL and Mbale District Local Government Leaders (MDLG). As leaders in HIL and MDLGL have priorities and values that guide their leadership, these will be looked at from a transformational view point.

\section{Leadership, education and political dynamics}

Musaazi (2006) indicates that to make education a profitable enterprise and a contributor to social development, planning must come to be accepted as the essential prerequisite. Planning is an activity in which individuals, organizations, communities and countries are always engaged. It is among other things, a professional activity with an area of academic enquiry. For this reason, Mbale as a District is made by a variety of people groups. It is governed by political leaders representing the government at national, regional, and local levels. These leaders are expected to initiate educational planning that must involve HIL. In line with Musaazi's position, the authors of this article would like to assess to what extent Mbale District Local Government leaders in Mbale District have involved schools in order to educate them on issues concerning the roles schools can play in favor of not only the HIL but also the District development.

\section{Study rationale and purpose}

The rationale for this study was to create awareness of the role School leadership in HIL in Mbale district can play in the effort to lead Mbale District to its true development. The purpose of the study was to find out opportunities in HIL that are likely to be used in order to induce, maintain, and promote sustainable development.

\section{Research objectives}

For this particular study, the main objective was to determine opportunities in HIL that can enable Mbale District to induce, maintain, and promote sustainable development in Mbale District.

\section{Research question}

The research question was to find out which opportunities are there in HL that can help Mbale District take-off as far as sustainable development is concerned.

\section{Scope of the study}

This study was limited to school leadership in HIL. It was primarily focused on opportunities, existing in HIL that leaders from both HIL and MDLGL could be used to induce, maintain, and promote sustainable development of both individuals and communities within Mbale District.

\section{Theoretical scope}

In this study and from the theoretical perspective, school leadership had focus on both transformational and pragmatic research paradigms. The two lead to intentional and practical application of knowledge in order to induce, maintain, and promote integral development that leads long-lasting development. 


\section{Geographical scope}

The research work was done in Uganda in Mbale District and did involve HIL that were fully accredited by the National Council for Higher Education and which are completely functioning in the District at the time the research was conducted.

\section{Time scope}

The study was conducted in Mbale District from July $1^{\text {st }}$ to July $31^{\text {st }} 2017$.

\section{Significance of the study}

Kaahwa (2008) indicates that the significance of the study shows the worth, urgency and need for undertaking the study. This study of school leadership was meant to expose opportunities in HIL that could be considered as catalysts of sustainable development. Mbale being a developing District, it is more than urgent to involve HIL in the plans to develop the District so that HIL share the opportunities they have which are indispensable for the holistic development of Mbale for more sustainability.

The significance of this project is that HIL can offer a platform for Mbale District to solve its problems through applied research for development. In fact, Musaazi (2006) says that "The planning process is seen as a professional activity, as well as a social process located at the interface between knowledge and authority." HIL have both knowledge and authority in different disciplines that Mbale District needs to consider as it plans for its long-lasting development.

\section{Proposed study paradigm}

Rapid, sweeping and long-lasting change is altering our planet environment in and unprecedented manner, while societies are undergoing profound shifts in their demographic makeup and social economic fabrics. Political agreements, financial incentives or technological solutions alone do not suffice to grapple with the challenges and sustainable development. It will require a wholesale change in the way we think and the way we act- a rethink of how we relate to one another and how we interact with the ecosystems that support our lives (UNESCO, 2014). To create a world that is more just, peaceful and sustainable, all individuals and societies must be equipped and empowered by knowledge, skills, and values as well as be instilled with heightened awareness to drive such a change (Ibid.). Because of this, the model we are going to use to orient this research is from a pragmatic paradigm dimension of research for positive transformation. Effective leadership should lead to practical application of knowledge for both individual and collective transformation.

Leadership development doesn't happen overnight. To achieve genuine, sustainable results, leaders in the "Pragmatic leadership" Program are exposed to six different learning dynamics, which, when combined, influence and enable meaningful, longer-term growth (www.pragmaticleadership.ca). This theory is made up with dynamics which represents a force that stimulates change or progress within a system or process (Ibid). The dynamics include: self-reliance, blended learning, coaching, academic theory, applied learning, sponsored accountability. To these six elements, the researchers have added one more key element that it is at the center of the diagram and without which self-reliance cannot take place. That added document was intentional action. All those seven elements are represented in the diagram below: 
DOI: 10.21522/TIJAR.2014.04.02.Art004

ISSN: 2520-3088

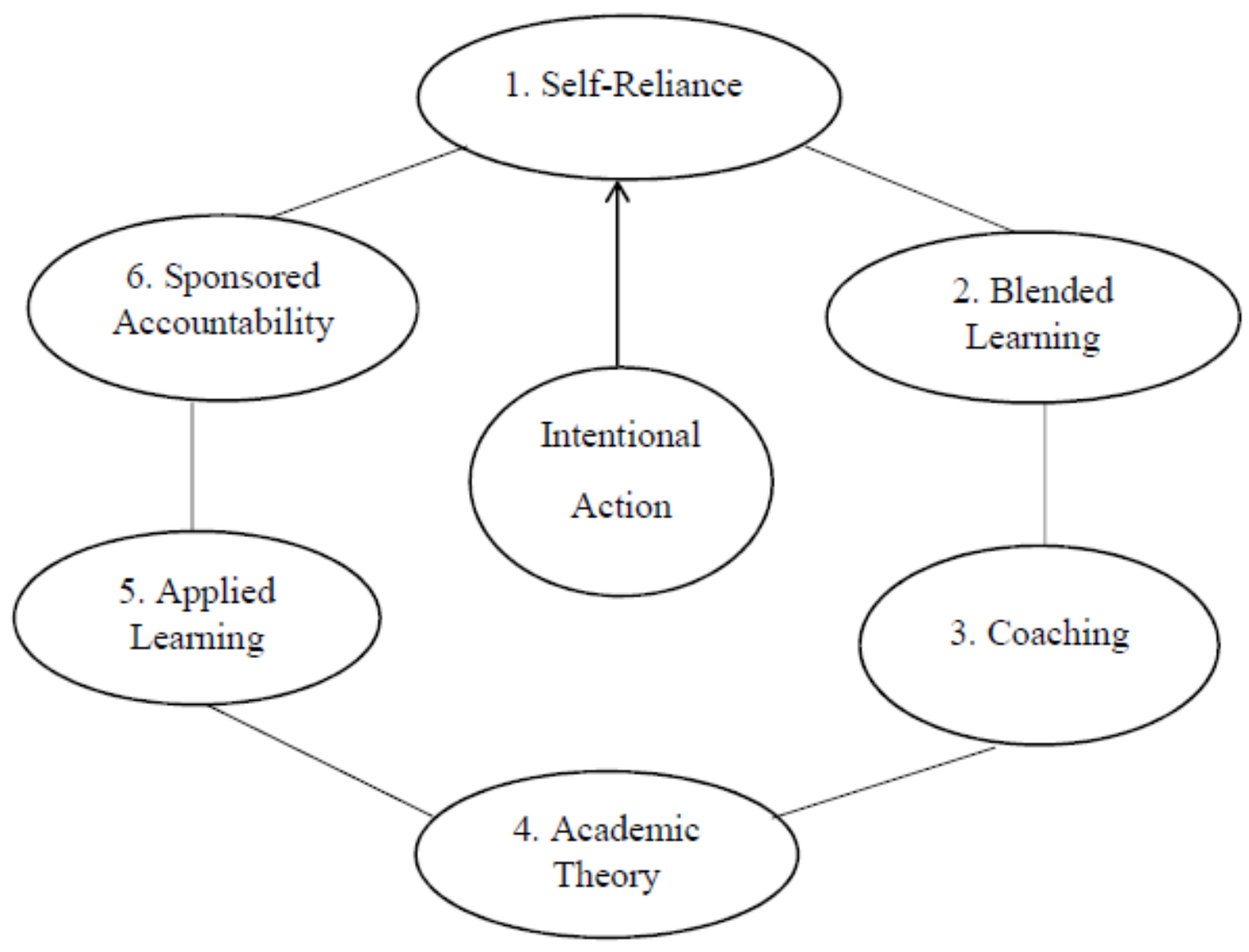

Figure 1. Pragmatic Leadership/Researcher

\section{Future perspectives on school leadership and development}

School leadership should come closer to governments and communities in Mbale District so that they work together in the effort to promote holistic, long-term and sustainable development. Development cannot take place without citizens having sound knowledge, appropriate attitudes and useful skills. It is therefore important for us to determine in Mbale District, school leadership opportunities that can lead Mbale to real development which must be integral for more sustainability.

\section{School leadership opportunities in higher institutions of learning}

There is an urgent need to study school leadership setting especially in HIL and assess how people and systems are influenced. HIL offer a more reliable platform to exercise leadership. Both students and staff in such institutions can be taught and practice leadership. Topping (2002) says, if we can teach them how to be more effective leaders, even very modest improvements in each person can reap big rewards for the entire organization. So can leadership be taught? Not in the way we can teach mathematics or discounted cash flow, but a heightened understanding of how leadership behaviors affect others and impact performance can help anyone enhance his or her effectiveness. And isn't any gain in this area worth the effort?

There is no doubt that there is gain in perspective. What is important is to see what is happening and consider it as an opportunity to learn, and analyze the situation and make necessary adjustments for change. But it is important to know that, "All organizations trough history have needed and displayed varying levels of success with their own leadership. And the word does not just consist of Europe and 
America. Leadership was, is, and always will be a global issue, one which involves all people, whatever their organizational or social setting (Hooper and Potter, 2001). From a global education perspective, efforts have been made to help countries in the developing world. It is one thing to help a country deliver the right to basic education; it is quite another thing to agree to help secure that right for the foreseeable future (King, 2004).

There is a great need of developing special partnerships that will enable HIL to play their noble role in causing development through educational opportunities. Klees (2001) suggests that, "Education and development rhetoric over the past decade has increasingly focused on the idea of partnerships as central to improving policy. Such policy can help cause and deepen relationship between HIL and the government organizations at different levels of social interactions. Apart from these partnerships, freedom of thoughts is also another opportunity for development. Innovations come from ideas.

In fact, "interplay between the Reformation and the Renaissance was an important moment in history of freedom of thoughts." (Mazrui, 1979). Such freedom of thoughts can lead to innovations and positive change. Change does occur, however, when local actors with clear ideas of new kinds of education are given authority to act (1997). Local actors can be products of globalization. In this instance, globalization becomes an opportunity for development that institutions and governments in different countries should consider. In relation to this Yang (2003) says, "Nowadays, international contexts have to be taken into account when higher education in developing countries has begun to integrate into the world community to meet with the global demands and even conform to the international practice." Goldstein, Miller, and Courson (2014) support that, "Whether from financial crises, global competition or disruptive technologies, higher education is irrevocably changing, causing each institution to re-evaluate its mission, practices, and operational model." This should be done in consideration to local political, economic, social, and cultural dynamics of the communities in which these institutions have been established. In Africa, Musaazi (2011) the sociopolitical objectives of Education in Nigeria, Uganda, and Kenya are relatively unformulated beyond vague invocations to educational institutions to promote democracy, egalitarianism, self-reliance, respect for dignity of labour and to adopt a rural orientation and to install nationalism. The education system in any country should consider what Musaazi is indicating here. A lot needs to be done in order to better the education system in Africa if we truly need to lead true democracy, egalitarianism, self-reliance, and respect for dignity of labour to adopt rural orientation and to install nationalism. For all this to become reality, there is need for political will to create a paradigm that will be more pragmatic in nature and which must lead to a redefinition of sociopolitical objectives of Education in most countries in Africa.

Uganda as a country is aware of that change and is making necessary efforts to improve the quality of leadership and education in HIL. HIL are frequently challenged by mandated Education Officers to revisit their mission, practices and operational model in order to comply with set standards for quality assurance that will allow Africa and Uganda in particular to be effective catalysts of educational dynamics as far as globalization and its effects on education and development are concerned.

The youth population is Uganda is a concern for educational professionals in Uganda. As pointed out the youth population in Africa is very high. The Guardian (2014) reveals that Uganda has the world's largest percentage of young people under $30-78 \%$ - according to the to the 2012 State of Uganda population report by the UN Population Fund (Ibid.). In interview with the Deputy Resident District Commissioner, the Commissioner in a Press Conference on the youth confirmed that actually the youth population in Uganda is now estimated at 78\% (Interview, RDC Office in Mbale (2017).

This population is an opportunity that needs to be critically looked at as far as school leadership in HIL and development are concerned. In this youth, lies the future of Mbale District, Uganda and Africa. Research should continue to dig deep and plan for the youth so that this opportunity may not soon become a threat for development. Unemployment of the youth is a kind of latent bomb that has to be deactivated without delay. 
DOI: $10.21522 /$ TIJAR.2014.04.02.Art004

ISSN: $2520-3088$

In the past decade, Uganda has experienced strong GDP growth, averaging 7\% annually, but this has not generated jobs, a trend seen across the continent. Lack of employment is causing some young people to take risks. Last July, 36 young people, who had been running motorcycle taxis, were burnt to death as they tried to siphon fuel from a truck that had been involved in an accident (The Guardian, 2014). And some young women are taking jobs overseas only to find themselves forced into prostitution, according to Ugandan police. "Every month, we get reports of over 20 Ugandans stranded seeking help. If the figure is multiplied in a year, it comes to over 250 Ugandans stranded abroad every year," says Moses Binoga, Coordinator of the Anti-human Trafficking National Task Force (Ibid). Other young people are involved in drug trafficking. Dr. Paul Nyende, a Senior Lecturer at Makerere University's School of Psychology, says young people with nothing to do are more easily lured into crime. "They can easily be lured into drug trafficking on promise of big pay," he says. "Many young people don't want to go back to the villages and do farming after campus. They want to stay and enjoy city life." (Ibid). Yet the city cannot support them. It is estimated that more than 40,000 young people graduate from Ugandan universities each year. Yet the market can provide only 8,000 jobs annually (Ibid).

This report is given for Uganda in general and the authors would like to analyze this trend in the context of Mbale District. How can HIL and MDLG sit together and critically think about the youth and discuss how this youth can be seen more as an opportunity rather than a threat? There is a need for HIL and the District to plan and see how this opportunity can be used for integral development that leads to more sustainability.

The same report indicates that worldwide, there are about 1.2 billion 15- to 24-year-olds. About 200 million are in Africa. This portion of the world's population needs to be considered as a reliable springboard for sustainable development for the world but more urgently for developing countries, Uganda included. The NCHE has developed a quality framework for effective governance in HIL but at the same time other indispensable bodies have been established to ensure quality such as the UQUAF give a significant path that will lead to relevancy of education vis-à-vis needs. This enables the establishment of strategic plans for sustainable development.

In relation to Mbale District, the educational system is in place. It counts quite a number of Public Universities and Private Universities and Tertiary Institutions. Educational efforts are seen in Mbale. Research shows that new universities are coming up such LivingStone International University, the latest established University in Mbale. If it is not new, old existing universities are extending themselves by establishing extension campuses in Mbale.

The researcher believes they have seen great opportunities through HIL. But the question remains: which opportunities are there in Mbale that are causing HIL to target Mbale District? Is Mbale District aware of such HIL opportunities? How can HIL work together with government so that sustainable development is promoted? Here is where education, research and technology can be used to pave true way to sustainable development. Embracing it from a global perspective will be absolutely the blood system of sustainable development for Mbale District.

\section{Study methodology}

This study used a qualitative research approach; Interview and Focus Group Discussions.

\section{Location of the study}

The study was conducted in Mbale District, Uganda as it was pointed out in the scope section of this study report.

\section{Population and sampling technique}

The population was made by administrators and leaders at different level in three HIL in Mbale District: LivingStone International University (LIU), Uganda Christian University (UCU), and Uganda Martyrs University (UMU). The sampling technique was convenient and purposive in nature. 


\section{Data collection instruments}

For the Interview, structured interview was used and for the Focus Group Discussion, a moderator guide was used to orient discussions.

\section{Data analysis}

Data was collected; analyzed, recorded, and categorized in relation to the object of the study. A recording has been secured for whomever would like to use it for one or another reason and was saved under an audio file called "Buregea Henry"

\section{Ethical considerations}

The research topic and objectives were thoroughly explained to respondents before answering the study questions for both interviews and focus group discussions. Participants were clearly informed that the information that was to be collected was meant to be used only for academic purposes. Authors made sure consents were got from participants before interviews and Focus Group Discussions were conducted and recorded. From start to the end, the works of others were systematically recognized.

\section{Findings of the study}

Participants during both interviews and focus group discussions pointed out the following as being significant opportunities that MDLGL should see in HIL and which can enable development take-off:

- HIL are considered to be source of any knowledge that can be used to address all needs of Mbale District. For this very reason, HIL are indispensable for the District's development.

- HIL's opportunities give chance to the District to revisit its development policies and other policies in favor of HIL so that District leaders involve leaders of HIL in the District policy formulation.

- HIL are centers of Capacity Building for any potential applicants for capacity building and these can be either nationals or internationals; individuals or groups; governmental or non-governmental. Mbale District could fall into the category of national and government organization. This is an opportunity to train for sustainable development.

- HIL and Local Government (Mbale District) for instance can work together to do research within the District and these research will be operational in nature so that needs within the District can be addressed basing on a scientific road to sustainable development.

- HIL is where technology is developed and knowledge created and innovated. There is technological know-how in HIL that needs to benefit Mbale District for any innovation they would like to initiate and or promote in the District.

- HIL can organize trainings for Local Government Employees. Such training should target sustainable development.

- HIL and MDLGL are opportunities to train the youth for sustainable development. Actually Ugandan population is very young and should be seen as a golden opportunity for targeted training for sustainable development. If global and national education initiatives realize that, investments can be attracting the youth first and secondly the other categories of the population.

\section{Conclusion and recommendations}

In Conclusion, Opportunities are there and it is only a matter of Leaders of HIL and Mbale District Local Government to work together. Thus, the following recommendations are formulated:

- HIL and MDLG should come together and create a development platform that will allow regular meetings to discuss available opportunities and possible means to use in order to find a way to induce, maintain, and promote integral development of both individuals and communities who live in Mbale District.

- Using the Pragmatic Leadership Model proposed by the authors, leaders of HIL and MDLG will not only discuss but they should come to substantive resolutions that will lead to the planning of 
DOI: $10.21522 /$ TIJAR.2014.04.02.Art004

ISSN: $2520-3088$

different activities, and do a thorough opportunity analysis, identify relevant means and potential national and international development partners that will support both HIL and Mbale District Local Government at all phases of the Mbale District development process.

- Establish a development consortium composed of leaders of HIL and MDLG to follow up on development resolutions and significantly engage key stakeholders students, staff, youth, community leaders, cultural leaders, religious leaders, District member of Parliament as well as other administrative and political leaders and development agencies who have Mbale at heart.

- Develop partnerships with national and international organizations who strive to combine education, research, technology and development for more sustainability.

\section{References}

[1].Hopper \& Potter (2001) Intelligent Leadership. USA: Random House Business books https://www.csrmatch.org/project/transforming-communities-initiative-in-mbale-district-Uganda

Https://www.google.com/\#q=uganda+population.

[2].Kaahwa, M.G. (2008) Research Methodology: Made Simple. Kampala (UG): Sure Technical Association Ltd.

[3] (2007) A Search Engine For leaders, communicators, Researchers, and Educator in Research, Communication, Leadership, And Instructional Methods. Kampala: Sure Technical Association Ltd.

[4].King, K. (2004) The External Agenda of Educational Reform: A Challenge to Educational Self-reliance and dependency in Sub-Saharan Africa. Centre of African Studies, University of Edinburgh. CICE Hiroshima University, Journal of International Cooperation in Education, Vol 7, No.1, (2004) pp. 85.

[5].Klees, S. J. World Bank development Policy: A SAP in SWAPs clothing. Current Issues in Comparative Education, 3 (2)... article. USA: Columbia State University.

[6].Kornfield, D. (1989) Church Renewal: A handbook for Christian Leaders. USA: Baker Book House. Mazrui, A. A (1979) Churches and Multinationals in the Spread of Modern Education: A third World Perspective, Third World Quaterly, Vol. 1 (Jan. 1979), pp. 30-49.

[7].Musaazi, J.C.S (2011) Planning and Development in Education. New York: Routledge. (2006)

Educational Planning. Kampala: Makerere University Printery.

[8].Pragmatic Leadership (2014) Pragmatic Leadership. Retreieved from Http://www.pragmaticleadership.ca. Online publication, Cognascent, Inc.

[9].The Wallace Foundation (2016) School Leadership. New York: The Wallace Foundation. Tilbury, D. (2014) Higher Education for Sustainability, UNESCO Global Monitoring and Evaluation Expert Group for UN DESD, January 2005-December 2014. Retrieved from www.guninetwork.org.

[10]. The Guardian (2014) Global Development-Why is east Africa facing a hunger crisis and what can be done?podcast, Retrieved from https://www.theguardian.com/global-development/2014/jan/16/uganda-unemployedgraduates-held-back-skills-gap.

[11]. Uganda Bureau of Statistics (2014) National and Population Housing Census, Revised Edition Uganda, UBOS. Retrieved from

http://www.ubos.org/onlinefiles/uploads/ubos/NPHC/NPHC\%202014\%20PROVISIONAL\%20RESULTS\%20REP ORT.pdf.

[12]. UNESCO (2014) Roadmap for implementing the global action program on education for sustainable development. Paris: UNESCO.

[13]. UN System Task Team on Post 2015 UN Development Agenda (2012) Technological learning and innovation capacity: a cutting-issue for inclusive development (Science, technology and innovation for sustainable development in the global partnership for development beyond 2015).

[14]. Yang, R. (2003) Globalization and Higher Education Development: A Critical Analysis. International Review of Education 49 (3-4): 269-291, 2003. Netherlands: Kluwer Academic Publishers. 